\title{
Concept "humour" in the linguistic consciousness of the Russian-speaking population of Ukraine
}

\author{
Iuliia Kobzieva
}

H. S. Skovoroda Kharkiv National Pedagogical University, Ukraine yu.kobzeva88@gmail.com

\section{Iia Gordiienko-Mytrofanova}

H. S. Skovoroda Kharkiv National Pedagogical University, Ukraine ikavgm@gmail.com

\section{Maryna Udovenko}

H. S. Skovoroda Kharkiv National Pedagogical University, Ukraine udovenko0409@gmail.com

\section{Serhii Sauta}

H. S. Skovoroda Kharkiv National Pedagogical University sergeisauta@gmail.com

\begin{abstract}
The purpose of this study was to define and to describe the semantic components of the stimulus word humour in the linguistic consciousness of young Russian-speaking people from Eastern Ukraine. The main method of the research was a psycholinguistic experiment. The sample comprised 400 young people (aged 20-31), males and females being equally represented. The experiment proved that the concept humour in the linguistic consciousness of the Russianspeaking population of Ukraine is represented by four core semantic clusters: "laughter," "joke," "merry-making/joy" and "show." Analysis of female and male associative fields shows that the semantic core of the word humour does not depend on the respondents' gender identification. The results of frequency and cluster analysis have implied a number of the following conclusions. Firstly, humour and laughter form an inseparable unity of stimulus and reaction in the linguistic consciousness of respondents, although the psychological paradigm considers humour and laughter as two independent phenomena. Secondly, the cognitive component of humour was only reflected in the peripheral cluster "mind" of respondents' associations. Thirdly, young Russian-speaking people from Ukraine do not have an ideal image of humour represented by a certain comedy show or relevant to any specific comedians. The generalised visualisation of humour is represented by reactions of the extreme periphery. Finally, comparative analysis of the verbalised concept humour in the linguistic consciousness
\end{abstract}


of Russian-speaking population of Ukraine and people who live in Russia did not reveal any national-specific features in the perception of stimulus humour.

Keywords: ludic competence, playfulness, ludic position, humour, psycholinguistic experiment, free association test, linguistic consciousness.

\section{Introduction}

Researchers This article continues a series of studies devoted to ludic competence (GordiienkoMytrofanova \& Sypko 2015; Gordiienko-Mytrofanova \& Sauta 2016b; GordiienkoMytrofanova \& Kobzieva 2017a, 2017b, 2018, 2019; Gordiienko-Mytrofanova et al. 2018a, 2018 b). We define ludic competence as a system of inner resources to which a person turns in order to balance their personality against external conditions of the social environment on the basis of positive emotions, e.g. interest and joy, which are frequently expressed affectively and accompanied by tension and excitement. Ludic competence is formed alongside with the development of playfulness, which is a stable personality trait in the modern world of gamification (Gordiienko-Mytrofanova \& Kobzieva 2017a, 2017b).

As a stable personality trait, playfulness has been the subject of scientific research since 1975 (Csikszentmihalyi 1975; Groos 1976; Chapman 1978; Bowman 1987; Barnett 1990; Bundy 1996; Schaefer \& Greenberg 1997; Guitard et al. 2005; Shen 2010; Yarnal \& Qian 2011; Proyer 2012; 2013; 2017; Yue et al. 2016). We define playfulness as the individual creative adaptation to the reality of their own "Self" (individual identity) and to the reality of the World (social identity). As a result, every difficult situation can be faced as a challenge rather than a threat. This definition of playfulness is close to the one provided by Guitard et al. (2005: 19).

In Ukraine, we are among the few researchers studying playfulness (GordiienkoMytrofanova 2014a, 2014b, 2014c; Gordiienko-Mytrofanova \& Sypko 2015; GordiienkoMytrofanova \& Sauta 2016c) with the help of psycholinguistic methods and psycholinguistic experiments in particular, the main stage of which is free association test. Previously, we carried out the most extensive longitudinal free association test with the stimulus word playfulness (4,795 respondents). In order to explore common tendencies and characteristic features of the general population (which is the whole population of Ukraine aged 18-75 who are fluent in Russian) and meet the objectives of this research, several samples were formed. Respondents were selected quantitatively and qualitatively. ${ }^{1}$ Nineteen psycholinguistic meanings of playfulness were described as a result of the psycholinguistic experiment with a sample of 1,600 respondents (Gordiienko-Mytrofanova et al. 2019). Based on previous theoretical and empirical research of playfulness as a personality trait (Barnett 2007; Guitard et al. 2005; Proyer 2012; 2013; Yarnal \& Qian 2011; Shen et al. 2014), as well as analyses of components/scales of playfulness (Glynn \& Webster 1992; Tsuji et al. 1996; Schaefer \& Greenberg 1997; Barnett 2007; Yarnal \& Qian 2011; Proyer 2012; Shen et al. 2014; Proyer 2017), high-frequency reactions of the biggest sample of 4,795 respondents and established psycholinguistic meanings, we managed to single out the following components of playfulness: sensitivity, imagination, sense of humour, ease, flirting, impishness, fugue (Gordiienko-Mytrofanova \& Sauta 2016a;

\footnotetext{
${ }^{1}$ The way we formed our sample groups quantitatively and qualitatively was theoretically and experimentally explained in our previous study (Gordiienko-Mytrofanova et al. 2018b). The sufficient size of experimental sample varies from 400 to 1,500 people depending on the qualitative and quantitative features of general population and research conditions. One of the main strategies of sample formation is to single out strata followed by randomisation. In other words, we divide the general population into strata, i.e. groups that share certain parameters (gender, age, status, education, etc.) and apply randomisation.
} 
Gordiienko-Mytrofanova \& Kobzieva 2017a, 2017b, 2018, 2019; Gordiienko-Mytrofanova et al. 2018a, 2018b, 2019). The components of playfulness as an integral personality trait are also the components of ludic competence. We define them as "motivational predispositions" (Raven 2001). They help people achieve personal goals and stay in harmony with themselves and the outer world (Gordiienko-Mytrofanova \& Kobzieva 2017a).

This "motivational predisposition" forms the basis of ludic positions of effective social interaction: "sensitivity" (sensitive) - "aesthete;" "imagination" - "sculptor;" "ease" (easy) "balance-master;" "flirting" (flirtatious) - "diplomat;" "impishness" (impish) - "frolicsome fellow;" "humour" (funny) - "real humourist;" "fugue" (fugue) - "holy fool." Ludic positions reflect the way ludic competence manifests itself in different standard and non-standard situations, which brings about behavioural aspect. Therefore, mastering ludic positions means mastering certain behavioural patterns. The names of ludic positions are justified both theoretically and empirically (Gordiienko-Mytrofanova \& Kobzieva 2017b; 2018; GordiienkoMytrofanova et al. 2018a) and were tested during ludic competence coaching sessions, which are part of the curriculum of psychology students in H.S. Skovoroda Kharkiv National Pedagogical University.

Being mentioned above, humour is one of the components of ludic competence. Humour is a part of several scales designed to measure playfulness: Playfulness Scale for Adults (Schaefer \& Greenberg 1997); Older Adult Playfulness Scale (Yarnal \& Qian 2011). It is also worth mentioning questionnaires where joy is used as one of the scales of playfulness rather than humour: Adult Playfulness Scale (APS) (Glynn \& Webster 1992); Adult Playfulness Trait Scale (APTS) (Shen et al. 2014).

We approached humour as a component of ludic competence from a psycholinguistic angle since psycholinguistic methods prove to be extremely effective in studying phenomena that are popular lexemes in the linguistic consciousness of respondents (GordiienkoMytrofanova \& Sauta 2016c), and humour is definitely one of them. With this purpose, we carried out the free association test with a stimulus word humour. In particular, in our ludic competence coaching sessions we use the results of the psycholinguistic experiment that help us consider gender-specific differences in the perception of humour, emotional attitude to humour, popular meanings of humour that are typical of the linguistic consciousness of the Russian-speaking population of Ukraine, ${ }^{2}$ etc.

In our ludic competence coaching sessions we considered humour as 1) ability to understand and use healthy humour (Martin 2007), i.e. affiliative and self-enhancing humour bringing emotional satisfaction, strengthening social bonds and influence, providing selfactualisation and a way to cope with difficulties (self-enhancing black humour); 2) ability to react adequately to unhealthy humour (aggressive and self-defeating) within acceptable social norms. These components correlate with a ludic position that we called "real humourist" and were described in detail in our previous publications (Gordiienko-Mytrofanova \& Kobzieva 2017a, 2017b; Gordiienko-Mytrofanova \& Pashchenko 2017).

The present article describes the results of a joint research effort (2015-2018) into the stimulus humour conducted by I. Gordiienko-Mytrofanova, I. Kobzieva, M. Udovenko and S. Sauta. The aim of the present article is to use the method of applied psycholinguistic research to define semantic components of the verbalised concept humour in the linguistic consciousness of young Russian-speaking people living in Ukraine. The results of the research will be eventually used to describe the behavioural pattern of the ludic position "real humourist" taking into account meanings that reflect the linguistic consciousness of Russian native speakers. The

\footnotetext{
${ }^{2}$ Part of the sample that took part in the psycholinguistic experiment also participated in ludic competence coaching sessions.
} 
following objectives were outlined: to determine general features of the verbal behaviour of young respondents in the framework of studying the stimulus word humour; to suggest major strategies and ways of dividing associations triggered by the stimulus humour into semantic groups.

We consider it worthwhile to explain the meaning of some of the key terms used in this study, in particular - linguistic consciousness and verbal behaviour.

Linguistic consciousness is coined as "the aggregate of psychological mechanisms of speech generation and understanding, as well as retaining the language in consciousness, i.e., mental mechanisms that underlie a person's speech activity" (Popova \& Sternin 2007: 32). It should be noted that this approach describes linguistic consciousness from the perspective of psycholinguistics, science with the human linguistic consciousness in the context of its psychological reality as an exclusive object of study (Sternin \& Rudakova 2011).

The associative field obtained in the course of association experiment is "not only a fragment of the verbal memory of a human being, but also a fragment of the image of the world shared by a particular ethnos, reflected in the consciousness of an average representative of some particular culture, their motives and judgments, and, consequently, cultural stereotypes" (Ufimtseva 2009: 98). The scope and nature of reactions in associative fields tell us a lot about the word usage, revealing the content of the word which is psychologically common among the native speakers of the language.

Verbal behaviour refers to behaviour that includes verbal reactions, such as speaking, reacting to words, remembering verbal material, etc. In the framework of our research, verbal behaviour is applied in a rather limited way, i.e. as written reactions to the stimulus words. ${ }^{3}$

\section{Methods}

The main method of the given research is a psycholinguistic experiment, whose major part is the free association test with the stimulus word humour. As additional methods, we used surveys (to refine the results of the free association test) and questionnaires (to specify the characteristics of the sample). As a mathematical-statistical method for the analysis of the results, we used frequency and cluster analysis allowing us to identify tendencies in the distribution of associations expressed by the experimental group.

The free association test with the stimulus word humour was conducted in a written form. Respondents were instructed to state their gender, age, education/specialisation, marital status, and write down the first five words that came to their minds somehow associated with the word humour. The total number of respondents was 400 young people (age 21-30), males and females equally represented. By education, 6.75 per cent were undergraduates, 27.25 per cent had a university degree, 11.5 per cent completed secondary school education, and 54.5 per cent did not state their education. By marital status, 21.5 per cent were married, 1.75 per cent had a partner, 76.75 per cent were single.

\section{Procedure}

\subsection{Building associative fields by five reactions and by the first reaction}

Frequency analysis of the free association test with the stimulus word humour enabled us to build associative fields by five reactions and by the first reaction. A total of 1,980 reactions were

\footnotetext{
${ }^{3}$ In this context, the term "verbal behaviour" is synonymous to the term "associative behaviour."
} 
expressed by the respondents (the results of the free association test by five reactions). Out of these, 477 reactions were unique, ${ }^{4}$ including 46 word combinations or complete sentences; 163 reactions with a frequency greater than one; 314 isolated cases $;{ }^{5} 0$ declined to answer the question.

As far as the first reaction is concerned, the free association test with the stimulus word humour yielded 400 associations, of which 130 reactions were unique, including 8 word combinations; 48 reactions with a frequency greater than one, 82 isolated cases, 0 declined to answer the question.

The comparative analysis of the associative fields (by the first and by five additional reactions) prompted the conclusion that the composition and nature of reactions had not changed significantly. What has changed, however, is the sequence of high-frequency reactions (cf. Figure 1), as well as the quantity of peripheral reactions and isolated cases. The latter can be easily explained by the greater number of respondents.

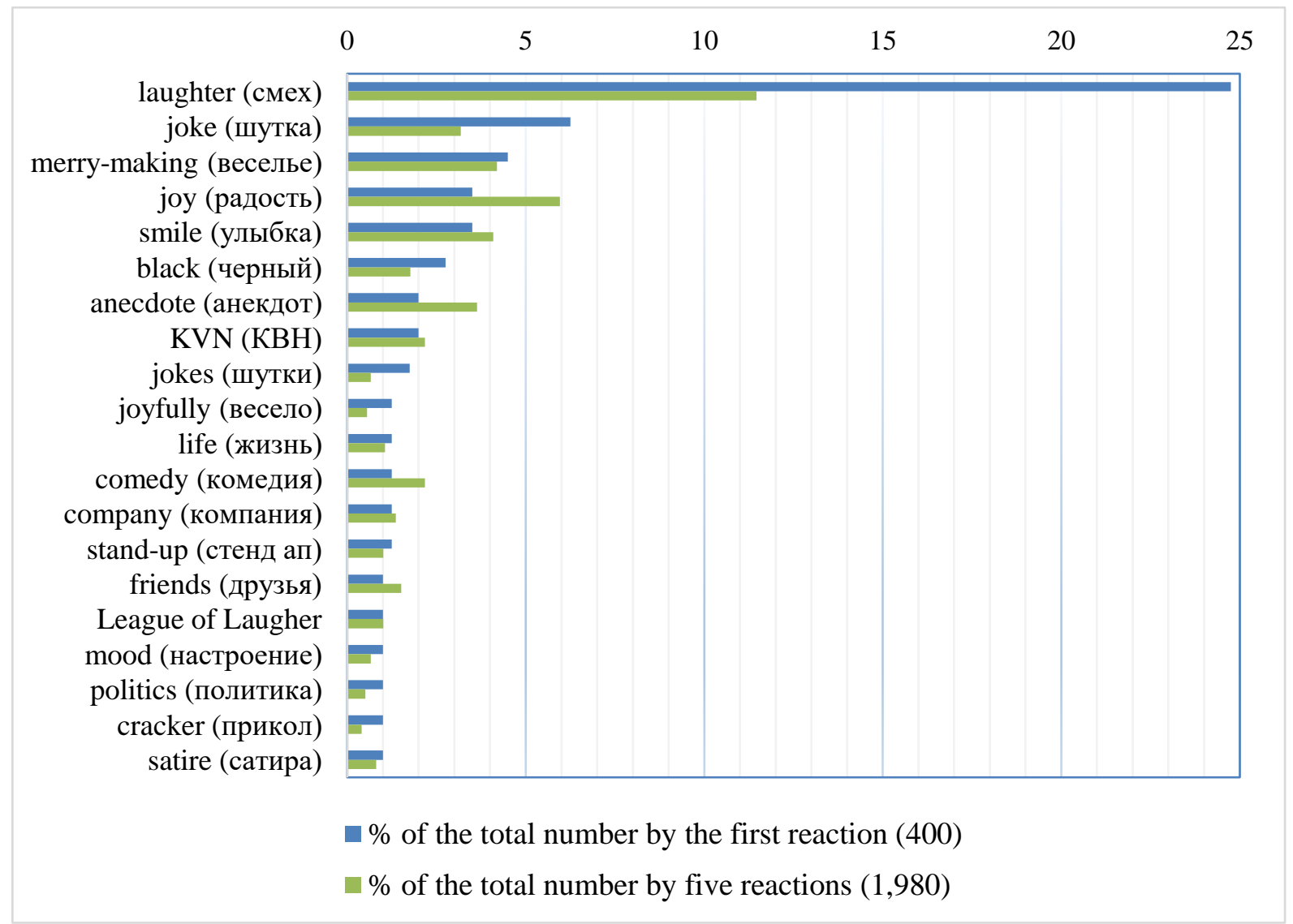

Note. League of Laughter (Лига Смеха) is a Ukrainian TV show; KVN (KBH) is a TV show where stand-up comics and humoristic teams perform and compete.

Figure 1. Comparative analysis of the associative fields by the first and by five additional reactions to the stimulus word "humour"

\footnotetext{
${ }^{4}$ Unique reactions are reactions expressed with different lexemes (Karaulov 2002a).

${ }^{5}$ Isolated cases are reactions with a frequency that equals 1 (Karaulov 2002a).
} 


\subsection{Partial semic interpretation of the results of the frequency analysis of the free association test with the stimulus word humour by the first reaction}

Partial semic interpretation of associative reactions involves combining cognate associations and nominations of the same semantic component expressed by different parts of speech, and also singular and plural forms of the same word.

Partial semic interpretation allows us to obtain more objective data on high-frequency associations and the quantity of different sememes that were revealed during the experiment. For example, laughter (cмех) 104 [laughter (смех) 99, funny (смешно) 3, hilarious (смешной) 2]; joke (шутка) 32 [joke (шутка) 25, jokes (шутки) 7]; merry-making (веселье) 23 [merry-making (веселье) 18, joyfully (весело) 5]; smile (улььбка) 16 [smile (улыбка) 14, smiles (улыбки) 2]; black (черный) 12 [black (черный) 11, gallows humour (чернуха) 1]; anecdote (анекдот) 9 [anecdote (анекдот) 8, anecdotes (анекдоты) 1]; friends (друзья) 7 [friends (друзья) 4, friend (друг) 2, girl-friend (подруга) 1]; mood (настроение) 5 [mood (настроение) 4, good mood (хорошее настроение) 1]; mind (ум) 5 [wittiness (остроумие) 2, mind (ум) 2, reason (разум) 1]; guffaw (ржач) 3 [guffaw (ржач) 2, big guffaw (ржачка) 1]; warmth (mеnлота) 3 [warmth (теплота) 1, warmly (тепло) 1, warm (теплый) 1]; innate (врожденный) 3 [innate (masculine form) (врожденный) 2, innate (neuter form) (врожденное) 1].

Analysis of the data from partial semic interpretation resulted in a changed sequence of some high-frequency associations in comparison with the reactions. However, the composition and nature of the associations remained the same. 


\subsection{Determining general features of the verbal behaviour of the young respondents}

Partial semic interpretation allowed us to outline general and specific features of the verbal behaviour of the young respondents (cf. Figure 2).

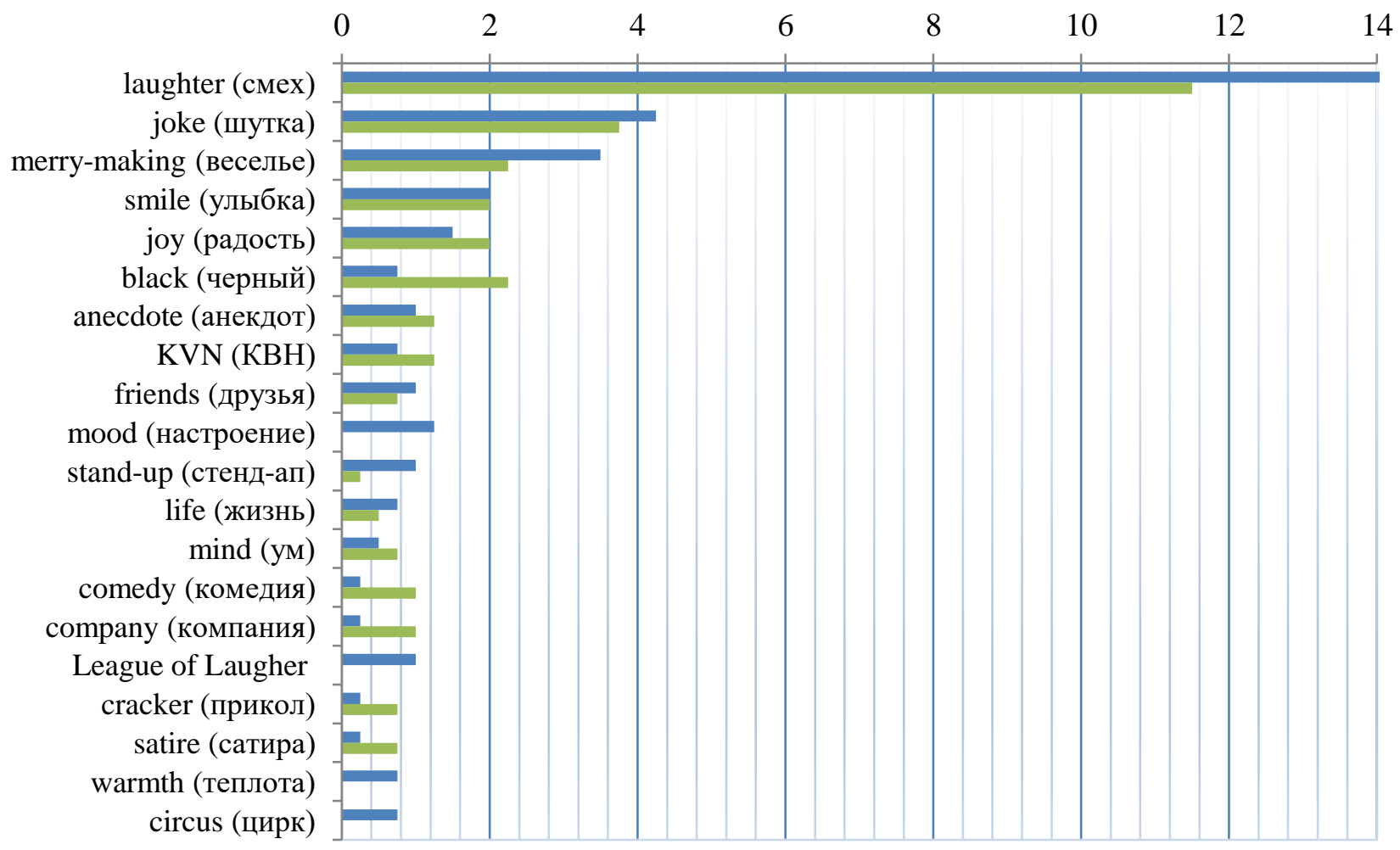

- Females, $\%$ of the total number of answers for the first reaction $(\mathrm{n}=200)$

Males, $\%$ of the total number of answers for the first reaction $(n=200)$

Figure 2. Comparative analysis of associations of female and male samples to the stimulus "humour"

Note. League of Laughter (Лига Смеха) is a Ukrainian TV show; KVN (KBH) is a TV show where stand-up comics and humoristic teams perform and compete.

The general features of the verbal behaviour of the young respondents are represented in the following lexemes (more than 1 per cent): laughter (смех) 104 (26 per cent), joke (шутка) 32 (8 per cent), merry-making (веселье) 23 (5.75 per cent), smile (ульбка) 16 (4 per cent), joy (радость) 14 (3.5 per cent), black (черный) 12 (3 per cent), anecdote (анекдот) 9 (2.25 per cent), KVN (КBH) 8 (2 per cent), friends (друзья) 7 (1.75 per cent), stand-up, life (жизнь), comedy (комедия), сотрапу (компания), mind (ум) 5 (1.25 per cent).

\subsection{Negative reactions}

The associative field of the stimulus humour had a number of reactions with negative connotation $^{6}$ (4 per cent). These are: guffaw (ржач) 3, stupid (mупой) 3, stupidity (2лупость),

\footnotetext{
${ }^{6}$ The researchers coded the reactions as positive or negative using Russian dictionaries providing information about emotional connotations of words (Dal 2011; Ozhegov \& Shvedova 2011; Ushakov 1935-1940; Yefremova 2000); e.g. GALLOWS HUMOUR (UEPHYXA) 2. Showing dark and grim aspects of every-day life (colloquial,
} 
side splitter (ор), mockery (стеб) 2, gallows huтоur (чернуха), dull (mугой), vulgarity (пошлятина), drunken тап (пьяный мужик) 1. The low number of negative reactions shows that the general attitude of the respondents to the stimulus humour is quite positive. No genderspecific reactions were revealed in this sample.

\subsection{Semantic clusters of the verbalised concept humour}

400 reactions obtained during the experiment were distributed among the following semantic groups/clusters: ${ }^{7}$

CORE CLUSTERS (more than 10 per cent):

1. "LAUGHTER" (“CMEX”): associations describing different reactions to humour: funny (смешно) 104 [laughter (смех) 99, fипnу (смешно) 3, hilarious (смешной) 2], smile (улььбка) 16 [smile (ульбка) 14, smiles (ульбки) 2], guffaw (ржач) 3 [guffaw (ржач) 2, big guffaw (ржачка) 1], roar (xохот) 3, side splitter (ор) 2 - 128 (32 per cent), f. 70 (17.5 per cent $), \mathrm{m} .58$ (14.5 per cent); $\mathrm{m} ., \mathrm{f} .=$ the frequency of male and female reactions; the first figure means the frequency, and the figure in parentheses shows the proportion of this reaction in the associative field.

2. "JOKE" ("ШУТКА"): associations referring to various types and forms of humour: joke (шутка) 32 [joke (шутка) 25, jokes (шутки) 7], black (черный) 12 [black (черный) 11, gallows huтоит (чернуха) 1], anecdote (анекдот) 9 [апесdote (анекдот) 8, anecdotes (анекдоты) 1], cracker (прикол), satire (сатира) 4, irony (ирония), story (рассказ), sarcasm (сарказм), тосkery (стеб) 2, red (красный), dialoguе (диалог), quirk (острота), parody (nародия), dirty cracks (подколь), various (разньий), leg-рull (розыгрыш), gentle (тонкий) 1- 76 (19 per cent), f. 31 (7.75 per cent), m. 45 (11.25 per cent). This cluster contains reactions that are fixed phrases, e.g. red huтоur (красный юмор), gentle hитоит (тонкий юмор), black hитоиг (черный юмор).

3. "MERRY-MAKING/JOY"

(“ВЕСЕЛЬЕ-РАДОСТЬ”): merry-making (веселье) 23 [merry-making (веселье) 18, joyfully (весело) 5], joy (радость) 14, mооd (настроение) 5 [mood (настроение) 4, good mood (хорошее настроение) 1], warmth (теплота) 3 [warmth (теплота), warmly (тепло), warm (тепльй) 1], harmony (гармония), love of life (жизнелюбие), lightness (легкость), knee-slapper (умора), happiness (счастье) $1-\mathbf{5 0}$ (12.5 per cent), f. 33 (8.25 per cent), m. 17 (4.25 per cent).

4. "SHOW" ("ШOY"): associations related to performing arts: $K V N(K B H) 8$, comedy (комедия), stand-up 5, League of Laugher (Лига Cмеха) 4, circus (цирк), Comedy Club 3, series (сериал), show (шоу) [show (шоу) 1, TV show (телевизионное шоу) 1] 2, concert (кониерт), TV program (передача), sеquеl (сиквел), sketch (скетч), theatre (теaтp), Kvartal 95 (95 Квартал) $)^{8}$, Sahara nе nado (Сахара не надо) ${ }^{9} 1$ - 39 (9.75 per cent), f. 23 (5.75 per

derogative) (Ozhegov \& Shvedova 2011: 707). The agreement between the researchers was reached up to 95 per cent. The reaction "black" is considered to be neutral, as it merely reflects a type of humour.

7 The reactions were distributed among various clusters on the basis of the algorithm of describing psycholinguistic meanings developed by I.A. Sternin. (Sternin \& Rudakova 2011). The authors of this article, I. Gordiienko-Mytrofanova and S. Sauta, collaborated with I.A. Sternin for 3 years and described the psycholinguistic meanings of the stimulus word "playfulness" with a sample of 1,600 respondents under his supervision.

${ }^{8}$ Kvartal 95 is Ukrainian production studio that creates comedy shows.

9 "Sahara ne nado" is a group of comedians from the Ukrainian TV show "League of Laughter." 
cent), m. 16 (4 per cent). This cluster is mainly represented by reactions that actualise precedent texts.

PERIPHERAL CLUSTERS (less than 10 per cent, but more than 1per cent):

5. “COMEDIAN" (“КОМИК”) - 19 (4.75 per cent), f. 5 (1.25 per cent), m. 14 (3.5 per cent). This cluster includes associations related to professions: clown (клоун) 3, performing artist (артист), comedian (комик), huтоurist (юморист) $1-6$ (1,5 per cent), f. 2 (0.5 per cent), m. 4 (1 per cent); associations that are specific examples of the stimulus: Zadornov (Задорнов), Petrosyan (Петросян) 3, Zelensky (Зеленский) 2, Nikulin (Никулин), Pavel Volya (Павел Воля), Ruki-bazuki (Руки-базуки), Trickster (Трикстер), Khazanov (Хазанов) 1- 13 (3.25per cent), f. 3 (0.75per cent), m. 10 (2.5 per cent).

6. "СОМРАNY" ("КОМПАНИЯ"): associations describing groups of people that spend time together mostly having fun: company (компания) 5, friends (друзья) 7 [friends (друзья) 4, friend (друг) 2, girl-friend (подруга) 1], collective (коллектив), youth hostel (общежитие) 1- 14 (3.5 per cent), f. 5 (1.25 per cent), m. 9 (2.25 per cent).

7. "MIND" ("УМ"): cognitive associations: mind (yм) 5 [wittiness (ocmpoyмuе) 2, mind (ум) 2, reason (разум) 1], innate (врожденный) 3 [innate (masculine form) (врожденный) 2, innate (nеuter form) (врожденное) 1], intellect (интеллект) 2, inner (внутренний), vocation (призвание) 1- 12 (3 per cent), f. 6 (1.5 per cent), m. 6 (1.5 per cent).

8. “OUTER WORLD" (“ВНЕШНИЙ МИР"): associations describing the outer world (nature, objects): life (жизнь) 5, colours (краски) 2, glitter (блестки), tree (дерево), hетр (конопля), sun (солнце), telephone (телефон), fireworks (фейерверк), balloons (царики) $1-14$ (3.5 per cent), f. 9 (2.25 per cent), m. 5 (1.25 per cent).

9. “THIS IS, FOR EXAMPLE” (“ЭТО, НАПРИМЕР"): associations containing examples: friend (друг) 2, girl-friend (nодруга), drunken man (пьяный мужик), опе's оwn (свой), I (я) 1 - 6 (1.5 per cent), f. 3 (0.75 per cent), m. 3 (0.75 per cent).

CLUSTERS FROM EXTREME PERIPHERY (no more than 1per cent, but more than 0.25 per cent):

10. "РОLITІСS" ("ПОЛИТИКА"): associations referring to public life: politics 4 4 (1 per cent), $\mathrm{m}$.

11. "CHARACTER:" behavioural associations: exit (buxod), confidence (уверенность), character (характер), goal (цель) 1-4 (1 per cent), m. 2 (0.5 per cent), f. 2 (0.5 per cent).

12. "ТУ" (“ТЕЛЕВИДЕНИЕ”): associations describing multiple informational channels: TV (телевидение) 2, YоиTube (ютуб), conversation (разговор) 1-4 (1 per cent), m.

13. “REST" (“ОТДЫХ"): associations connected with leisure activities: entertainment (развлечение), rest (oтдых), game (игра) $1-\mathbf{3}$ (0.75 per cent), f. 1 (0.25 per cent), m. 2 (0.5 per cent).

14. "ВОDY РАRTS" (“ЧАСТИ ТЕЛА"): associations related to different parts of human body: chest (грудь), fасе (лицо) $1-2$ (0.5 per cent), f. 1 (0.25 per cent), m. 1 ( 0.25 per cent).

15. Theological associations: God (Бог), soul (душа) $1-\mathbf{2}$ (0.5 per cent), m. 
16. "VERSATILITY" ("МНОГОГРАННОСТЬ"): associations reflecting the diversity of types of humour: versatility (многогранность), diverse (разный) $1-\mathbf{2}$ (0.5 per cent), f. 1 (0.25 per cent), m. 1 (0.25 per cent).

\section{ISOLATED CLUSTERS:}

17. "PЕRSON" (“ЧЕЛОВЕК"): associations actualising the arch-seme "person": person (человек) 1- 1 (0.25 per cent), $\mathrm{f}$.

18. "YOUTH" ("ЮНОСТЬ"): age-related associations: youth (юность) - 1 (0.25 per cent), f.

19. "ВRITISH" (“БРИТАНЦЫ"): associations related to nationalities: the British (британщзы) - $\mathbf{1}$ (0.25 per cent), $\mathrm{m}$.

20. “ОDЕSSА" (“ОДЕССА"): associations connected with Ukrainian cities: Odessa (Oдеcсa) - 1 (0.25 per cent), f.

\section{GENERAL EVALUATIVE REACTIONS:}

"RECEIVED WITH APPROVAL" ("ВЫЗЫВАET ОДОБРЕНИЕ"): positive (позитив) 2, kind (добрый), cool (круто), сите (мильй), peaceful (мирный), soft (мягкий), dear (родной), warm (тепльй), fascinating (увлекательный) $1-\mathbf{1 0}$ (2.5 per cent), f. 7 (1.75 per cent), m. 3 (0.75 per cent).

“RECEIVED WITH DISAPPOVAL" (“ВЫЗЫВАET НЕОДОБРЕНИЕ"): stupid (mупой) 3, stupidity (глупость) 2, vulgarity (пошлятина), weak (слабый), dull (тугой) 1-8 (2 per cent), f. 3 (0.75 per cent), m. 5 (1.25 per cent).

\section{Discussion}

Regarding the free association test with the stimulus word humour in the Russian language, we are aware of research conducted by Russian scholars Karaulov et al. (2002a, 2002b) in the 1990s that described the results of the free association test with the stimulus word humour. It should be noted that their Russian sample, which is similar to ours both in size and age (212 respondents aged 17-25), expressed many negative reactions to the stimulus humour (13.2 per cent) (Karaulov et al. 2002a). On the contrary, the overall attitude of the Russian-speaking respondents from Ukraine to the stimulus humour was quite positive (reactions with negative connotation accounted for mere 4 per cent).

Below are the results of the associative field of the stimulus word humour provided by the Russian Dictionary of Associations. We processed them in the same manner as it was described in Section 3.4:

HUMOUR (ЮMOP): laughter (смех) 39; black (черный) 23; satire (camupa) 15; wacky (плоский) 13; gentle (тонкий) 9; tongue-in-cheek (острый) 7; anecdote (анекдот) 5; wearing short trousers (Russian phrase for children's huтоur) (в коротких штанишках), satire (сатира); funny (смешно) 4; English (английский), to laugh (смеяться), good (хороший) 3; теrry (весельй), merry-making (веселье), Vokrug Smeha (Вокруг смеха), healthy (здоровый), to have (иметь), grim (мрачный), witty (остроумный), joke (шутка), huтоитіst (юморист) 2; big (большой), joyfully (весело), in short trousers (в штанишках), foolish (глупый), rude (грубый), lips (губы), kind (добрый), soul (душа), caustic (едкий), spiteful (ехидный), cruel (жестокий), life (жизнь), Zadornov (Задорнов), to take up (заняться), Ivanov (Иванов), sorrow (горе), KVN (КВН), 
Koklyushkin (Коклюшкин), сотрапу (компания), short (короткий), fly agaric (мухомор), soft (мягкий), unclear (непонятный), Odessa (Oдесса), weapon (оружие), I like very mисh (очень люблю), Petrosyan (Петросян), girl-friend (подруга), vulgar (пошльй), sign (признак), cracker (прикол), lol (пять баллов), rarity (редкость), homeland (родина), Russian (русский), sarcastic (саркастический), wry (с горчинкой), sex (секс), serious (серьезный), More cigarettes (сигареты More), hilarious (смешной), barrack-room jokes (солдатский), saves (сnасает), dark (темный), terror (террор), stupid (тупой), clumsy (тяжеловесный), terrible (ужасный), smile (ульюбк), Khazanov (Хазанов), ha-ha (хаxa), good company (хорошая компания), roar (хохот), feeling (чувство), schnauzer (шнауцер), trousers (штаны), lame joke (шутка юмора), off the cuff (экспромтом), this is love (это любовь), humоrous (юмора) 1; 212 (number of respondents); 82 (number of unique responses); 2 (number of people with declined to answer the question); 60 (number of isolated cases).

(Karaulov 2002a: 744)

This shows that laughter is the most frequent reaction both in Ukrainian and Russian samples, i.e. respondents from both samples tend to associate humour with emotional reaction. Interestingly, Odessa was mentioned among isolated reactions in both samples. This city is considered to be the capital of humour and laughter for the entire post-Soviet territory. In general, the Ukrainian sample had a wider semantic scope and was more likely to express positive emotions towards the stimulus.

Another research that is worth mentioning was conducted by Kvasnyk (2013). She explored the subjective image of humour in the system of individual meanings. The research relied on the characteristics of the subjective image of humour from the association test. Also, the scholar analysed the subjective image of humour with the help of direct association test and provided interpretation of its factor structure (Kvasnyk 2014). The research was carried out in the Russian language in Donetsk National University on the basis of a sample including students studying psychology in their first and second years of study (35 and 47 people respectively).

The above-mentioned research carried out by Kvasnyk revealed that the system of individual meanings of respondents contains a generalised image of humour manifesting itself by means of referring to real people (Kvasnyk 2013: 12). This conclusion is only partially confirmed in our research by reactions actualising precedent texts and personified associations. However, they only account for 8.8 per cent. What is more, Kvasnyk found that Kvartal 95 Studio had numerous positive connotations and was almost considered to be a benchmark for humour. In contrast to that, our free association test showed that Kvartal 95 was an isolated case (0.25 per cent) whereas KVN, stand-up, League of Laughter, and Comedy Club accounted for 2 per cent, 1.25 per cent, 1 per cent, and 0.75 per cent respectively.

As for research works in other languages, we are aware of a series of experiments devoted to perception of humour and remembering humorous associations that was conducted by S. Stoyanova on the basis of Psychology Laboratories at South-West University "Neofit Rilski” in Blagoevgrad, Bulgaria, with a sample including 48 respondents (Stoyanova 2016) who also expressed positive reactions to stimulus humour (joy, happiness, entertainment, satisfaction, etc.).

The comparative cross-cultural research of different attitudes towards humour conducted by F. Jiang with the help of Implicit Association Test with a sample including 60 Chinese and 33 American students (Jiang et al. 2011) showed different attitudes to humour and seriousness between Chinese undergraduate students and American exchange students. Chinese respondents associated humour more frequently with negative (unpleasant) adjectives and seriousness with 
positive (pleasant) adjectives. The opposite pattern was found for the American group (Jiang 2011).

Our sample did not compile many adjectives that can be classified as pleasant or unpleasant - 32 (8 per cent) reactions. Out of these, 18 (4.5 per cent) reactions are unique. If we discard reactions represented by idiomatic phrases, fixed collocations and examples, e.g. inner (внутренний), innate (врожденный), red (красный), gentle (тонкий), black (черный), опе's own (свой) which do not contain any substantial information for interpretation, there are only 15 reactions-adjectives left (3.75 per cent). Out of these, 12 ( 3 per cent) reactions are unique. Among positive adjectives are hilarious (смешной) 2, kind (добрый), сите (мильй), peaceful (мирный), soft (мягкий), dear (родной), warm (тепльй), fascinating (увлекательный) 1 9 (2.25 per cent). Among negative adjectives are stupid (mynoü) 3, weak (слабый), dull (тугой) $1-5$ (1.25 per cent). There is one neutral reaction - various (разный) 1 (0.25 per cent). So, our sample shows the dominance of adjectives with positive and neutral connotations. The overall proportion of adjectives in our sample is only 4 per cent, which is not sufficient for making any conclusions as to whether respondents are likely to use adjectives to express their emotional attitude to humour.

\section{Conclusions}

The cluster analysis showed that the core of the verbalised concept humour is represented by four semantic groups: laughter (32 per cent), joke (19 per cent), merry-making/joy (12.5 per cent) and show (9.75 per cent). Three of these clusters coincide with the common features of respondents' verbal behaviour reflected in the following associations i.e.: laughter (26 per cent), joke (8 per cent), merry-making (5.75 per cent), smile (4 per cent), joy (3.5 per cent). Thus, the verbalised concept humour is mainly represented by lexemes that describe people's reactions to humour (laughter, smile) and their positive emotions (joy, merry-making), as well as lexemes that refer to various types and forms of humour.

The analysis of core clusters vividly showed that, firstly, humour and laughter form an inseparable unity of stimulus and reaction in the linguistic consciousness of respondents, although scholars studying the nature of humour and laughter consider them to be two separate phenomena (Martin 2007; Provine 2000). According to Jean Paul (1981: 145-146), "people first laughed and comedians appeared later."

Secondly, the cognitive component of humour in the linguistic consciousness of the Russian-speaking population of Ukraine was represented in the peripheral cluster MIND, which accounted for mere 3 per cent. This testifies to the fact that Ukrainian respondents in the same way as Russian respondents do not associate humour with cognitive characteristics. This is remarkable because according to Martin (2007: 6), humour, among other things, involves a number of certain cognitive elements. In particular, the essence of humour seems to be incongruity, unexpectedness, and playfulness. The scholar emphasises that there needs to be some aspect that causes us to appraise the stimulus as nonserious or unimportant, putting us into a playful frame of mind at least momentarily.

Thirdly, the analysis of reactions did not reveal any significant difference between male and female samples. It means that the semantic content of the concept humour does not depend on gender identification. The fact that clusters on the extreme periphery are exclusively represented either by female or male reactions (cf. Figure 2) is most probably explained by certain individual preferences in usage rather than by gender-specific tendencies.

Frequency analysis showed that young people do not have an ideal image of humour represented by a certain comedy show or embodied by actual comedians, humourists or stand- 
up artists. The generalised image of humour is represented by reactions on the extreme periphery and isolated cases: $K V N(K B H)$ 8, stand-up 5, League of Laughter (Лигa Cмехa) 4, Comedy Club 3, Kvartal 95 (95 Kвартал), Sahara nе nado (Caxapa не надо) 1; Zadornov (Задорнов), Petrosyan (Петросян) 3, Zelensky (Зеленский) 2, Nikulin (Никулин), Ruki-bazuki (Руки-базуки), Khazanov (Хазанов), Pavel Volya (Павел Воля) 1.

Comparative analysis of the concept humour in the linguistic consciousness of Russianspeaking people from Ukraine and from Russia did not reveal any national-specific features in the way stimulus humour is perceived by Russian-speaking population of Ukraine and people who live in Russia. The only difference was found in the semantic content of humour which is slightly wider in the linguistic consciousness of Ukrainian respondents. In addition, Ukrainian respondents are more likely to express positive and neutral reactions to this stimulus in comparison to the Russian sample.

As for the prospect of future research, we believe it is necessary to describe the behavioural pattern of the ludic position real humourist taking into account core and peripheral semes of the concept humour. We also think it is important to ensure that the participants of our ludic competence coaching sessions understand the fact that humour and laughter are different phenomena. It also appears essential to define a set of cognitive elements that define the essence of humour.

\section{References}

Barnett, L. (1990). 'Playfulness: definition, design, and measurement'. Play and Culture 3, pp. 319-336.

Barnett, L. (2007). 'The nature of playfulness in young adults'. Personality and Individual Differences 43, pp. 949-958.

Bowman, J. (1987). 'Making work play'. In G. A. Fine (ed.), Meaningful Play, Playful Meanings (pp. 61-71). Champaign, IL: Human Kinetics.

Bundy, A. (1996). 'Play and playfulness: What to look for.' In D. L. Parham \& L. S. Fazio (eds.), Play in Occupational Therapy for Children (pp. 52-66). St. Louis, MO: Mosby.

Chapman, J. (1978). 'Playfulness and the development of divergent thinking abilities'. Child: Care, Health and Development 4, pp. 371-383.

Dal, V. I. (2011). Tolkovyi Slovar Zhivogo Velikorusskogo Yazyka [Explanatory Dictionary of the Living Great Russian Language]: in four volumes. Drofa. Retrieved from http://slovardalja.net/

Csikszentmihalyi, M. (1975). 'Play and intrinsic rewards'. Journal of Humanistic Psychology 15, pp. 41-63.

Glynn, M. \& Webster, J. (1992). 'The adult playfulness scale: an initial assessment'. Psychological Reports 71 (1), pp. 83-103.

Gordiienko-Mytrofanova, I. V. (2014a). 'Leksikograficheskoie znacheniie slova "igrivost" (podgotovitelnyi etap psikholingvisticheskogo eksperimenta) [The lexicographic meaning of the word "playfulness" (preparatory stage of a psycholinguistic experiment)]' Psykholohichni perspektyvy - Psychological Perspectives 24, pp. 76-88 [in Russian].

Gordiienko-Mytrofanova, I. V. (2014b). 'Psikhologicheskoie soderzhaniie leksikograficheskikh znachenii slova "igrivyi" (podgotovitelnyi etap psikholingvisticheskogo eksperimenta) [The psychological content of lexicographic meanings of the word "playful" (preparatory stage of the psycholinguistic experiment)]'. Problemy suchasnoi pedahohichnoi osvity - Problems of Modern Pedagogical Education 46 (III), pp. 298-306 [in Russian]. 
Gordiienko-Mytrofanova, I. V. (2014c). 'Psikhologicheskaia interpretatsiia leksikograficheskogo opisaniia slova "igrivyi" [Psychological interpretation of the lexicographic description of the word "playful"]'. Problemy suchasnoi psykholohii -Problems of modern psychology 25, pp. 83-98 [in Russian].

Gordiienko-Mytrofanova, I. \& Kobzieva, Iu. (2017a). 'Playful competence: the access code to the inner resources'. Proceedings of the 15th European Congress of Psychology. Amsterdam, 11-14 July, p. 19.

Gordiienko-Mytrofanova, I. \& Kobzieva, Iu. (2017b). 'Humour as a component of ludic competence'. Visnyk of H.S. Skovoroda Kharkiv National Pedagogical University, Psychology 57, pp. 40-56.

Gordiienko-Mytrofanova, I. \& Kobzieva, Iu. (2018). "Concept "holy fool" in the linguistic world-image of the Russian-speaking population of Ukraine'. Psycholinguistics 24 (1), pp. 118-133. https://doi.org/10.31470/2309-1797-2018-24-1-118-133

Gordiienko-Mytrofanova, I. \& Kobzieva, Iu. (2019). 'Gender- and role-specific differences in the perception of the concept "impishness" (based on the results of a psycholinguistic experiment)'. Psycholinguistics 25 (1), pp. 33-48. https://doi.org/10.31470/2309-17972019-25-1-33-48

Gordiienko-Mytrofanova, I., Kobzieva, I. \& Sauta, S. (2019). 'Psycholinguistic meanings of playfulness'. East European Journal of Psycholinguistics 6 (1), pp. 19-31. https://doi.org/10.5281/zenodo.3371627

Gordiienko-Mytrofanova, I., Kobzieva, Iu. \& Silina, A. (2018a). 'Psycholinguistic meanings of the verbalized concept "holy fool" (based on the results of the psycholinguistic experiment)'. Visnyk of H.S. Skovoroda Kharkiv National Pedagogical University, Psychology 59, pp. 18-34. https://doi.org/10.5281/zenodo.2527863

Gordiienko-Mytrofanova, I. \& Pashchenko, S. (2017). 'Zdorovoie chuvstvo yumora psihoterapevta ili terapevticheskii yumor [Healthy psychotherapist's sense of humour or therapeutic humour]'. Metaforizaciia i transkulturnyi podhod v konsultacii i psihoterapii: sbornik nauchny statei-Metaphorization and transcultural approach to counseling and psychotherapy: a collection of scientific articles 32. International Higher School of Practical Psychology. Riga: Nash Dom, pp. 26-32.

Gordiienko-Mytrofanova, I., Pidchasov, Ye., Sauta, S. \& Kobzieva, Iu. (2018b). 'The problem of sample representativeness for conducting experimental and broad psychological research'. Psycholinguistics 23 (1), pp. 11-46. https://doi.org/10.5281/zenodo.1212360

Gordiienko-Mytrofanova, I. \& Sauta, S. (2016a). 'Playfulness as a peculiar expression of sexual relationships (semantic interpretation of the results of the psycholinguistic experiment)'. European Humanities Studies: State and Society 1, pp. 46-62. Retrieved from http://ehsss.pl/czasopismo/EHS-SS-01-2016.pdf

Gordiienko-Mytrofanova, I. \& Sauta, S. (2016b). "Lexeme "playfulness" in the reality of linguistic consciousness and in the mainstream research in psychology'. Proceedings of the 11th International Congress of ISAPL. Ivane Javakhishvili Tbilisi State University, 27-30 June.

Gordiienko-Mytrofanova, I. \& Sauta, S. (2016c). 'Igrivost yazykovogo soznaniia [The playfulness of linguistic consciousness]'. International Congress 'The Active mind: from humanitarian methodology to humanitarian practices', dedicated to the 80th anniversary of A.A. Leontiev. Moscow, 23-26 May.

Gordiienko-Mytrofanova, I. \& Sypko, A. (2015). 'Playfulness as a relevant lexeme in the bilingual linguistic consciousness of Ukrainian people'. East European Journal of $\begin{array}{llll}\text { Psycholinguistics, } & \text { 2(1), } & \text { pp. } & \text { 43-51. }\end{array}$ Retrieved from- 
http://esnuir.eenu.edu.ua/bitstream/123456789/9355/1/eejpl_journal_2_1_2015_sypko_ho rdiyenko_mytrofanova.pdf

Groos, K. (1976). 'The play of man: Teasing and love-play. In Brunner, J., Jolly, A. \& Sylva K. (eds.), Play, Development and Evolution. Middlesex, United Kingdom: Penguin Books, pp. 62-83).

Guitard, P., Ferland, F. \& Dutil, É. (2005). 'Toward a better understanding of playfulness in adults'. OTJR: Occupation, Participation and Health $25(1)$, pp. 922.https://doi.org/10.1177/153944920502500103

Jean Paul (1981). Prigotovitelnaia Shkola Estetiki [Preschool of Aesthetics]: Translation from German by A.V. Mikhailova. Moscow: Iskusstvo [in Russian].

Jiang, F., Yue, X. \& Lu, S. (2011). 'Different attitudes towards humor between Chinese and American students: Evidence from the Implicit Association Test'. Psychological Reports 109, pp. 99-107.

Karaulov, Yu., Cherkasova, G., Ufimtseva, N., Sorokin, Yu. \& Tarasov, Ye. (2002a). Russkii Assotsiativnyi Slovar [Russian Associative Vocabulary], Vol. 1. Ot reaktsii k stimulu [From Reaction to Stimulus], ca. 100,000 reactions. Moscow: LLC Astrel Publishers; LLC AST Publishers [in Russian].

Karaulov, Yu., Cherkasova, G., Ufimtseva, N., Sorokin, Yu. \& Tarasov, Ye. (2002b). Russkii Assotsiativnyi Slovar [Russian Associative Vocabulary], Vol. 2. Otstimula k reaktsii [From Stimulus to Reaction], ca. 7,000 stimuli. Moscow: LLC Astrel Publishers; LLC AST Publishers [in Russian].

Kvasnyk, H. (2013). 'Subyektivnyi obraz yumora: diagnosticheskiie vozmozhnosti tekhniki repertuarnykh reshetok [Subjective image of humor: diagnostic capabilities of repertory grid techniques]'. Severo-Kavkazskii psikhologicheskii vestnik 11 (3), pp. 9-12 [in Russian].

Kvasnyk, H. (2014). 'Doslidzhennia subiektyvnykh uiavlen pro humor asotsiatyvnym metodom [The research of subjective conception of humor with the associative method]'. Problems of modern psychology 23, pp. 215-226 [in Russian]. https://doi.org/10.32626/22276246.2014-23.\%p

Martin, R. (2007). The Psychology of Humor: An Integrative Approach. USA: Elsevier Academic Press.

Ozhegov, S. I. \& Shvedova, N. Yu. (2011). Tolkovyi Slovar Russkogo Yazyka [Dictionary of Russian Language]. Moscow: Mir i Obrazovaniie, Oniks.

Popova, Z. D. \& Sternin I. A. (2007). Semantiko-Kognitivnyi Analiz Yazyka [Semantic and Cognitive Analysis of Language]. Voronezh: Istoki.

Provine, R. (2000). Laughter: A Scientific Investigation. New York: Penguin Books.

Proyer, R. (2012). 'Development and initial assessment of a short measure for adult playfulness: The SMAP'. Personality and Individual Differences 53 (8), pp. 989-994. https://doi.org/10.1016/j.paid.2012.07.018

Proyer, R. (2013). 'The well-being of playful adults: adult playfulness, subjective well-being, physical well-being, and the pursuit of enjoyable activities'. The European Journal of Humour Research 1 (1), pp. 84-98.

Proyer, R. (2017). 'A new structural model for the study of adult playfulness: Assessment and exploration of an understudied individual differences variable'. Personality and Individual Differences 108, pp. 113-122. https://doi.org/10.1016/j.paid.2016.12.011

Raven, J. (2001). The Conceptualisation of Competence. New York: Peter Lang Publishing, Inc. Schaefer, C. \& Greenberg, R. (1997). 'Measurement of playfulness: a neglected therapist variable'. International Journal of Play Therapy 6(2), pp. 21-31. https://doi.org/10.1037/h0089406 
Shen, X. (2010). Adult Playfulness as a Personality Trait: Its Conceptualization, Measurement, and Relationship to Psychological Well-Being. (Doctoral dissertation). Retrieved from Pennsylvania State University Library Catalog (OCLC No. 859524715).

Shen, X., Chick, G. \& Zinn, H. (2014). 'Playfulness in adulthood as a personality trait: a reconceptualization and a new measurement'. Journal of Leisure Research 46 (1), pp. 5883. https://doi.org/10.1080/00222216.2014.11950313

Sternin, I. A., \& Rudakova, A. V. (2011). Psikholingvisticheskoie Znacheniie Slova i Yego Opisaniie [Psycholinguistic Meaning of the Word and Its Description]. Voronezh: Lambert [in Russian].

Stoyanova, S. (2016). 'A series of experiments on humour perception and memorization - a case of humour associations and remembering humorous stories'. The European Journal of Humour Research 4 (2), pp. 57-69. https://doi.org/10.7592/EJHR2016.4.2.stoyanova

Tsuji, Hit., Tsuji, Hei., Yamada, S., Natsuno, Y., Morita, Y., Mukoyama, Y., Hata, K. \& Fujishima, Y. (1996). 'Standardization of the Five Factor Personality Questionnaire: Factor structure'. International Journal of Psychology 31 (pp. 103-217). Proceedings of the XXVI International Congress of Psychology. Montreal, 16-21 August.

Ufimtseva, N. (2009). 'Obraz mira russkikh: sistemnost i soderzhaniie [Image of the world of Russians: the systemic characteristics and the content]'. Yazyk i Kultura - Language and Culture, pp. 98-111 [in Russian].

Ushakov, D. N. (ed.). (1935-1940). Tolkovyi Slovar Russkogo Yazyka [Dictionary of Russian Language ]: in four volumes. Moscow: Sov. Encyclopedia: OGIZ. Retrieved from http://feb-web.ru/feb/ushakov/ush-abc/0ush.htm

Yarnal, C. \& Qian, X. (2011). 'Older-adult playfulness: an innovative construct and measurement for healthy aging research'. American Journal of Play 4 (1), pp. 52-79. Retrieved from https://files.eric.ed.gov/fulltext/EJ985548.pdf

Yefremova, T. F. (2000). Novyi Slovar Russkogo Yazyka. Tolkovo-Slovoobrazovatelnyi [New Dictionary of the Russian Language. Interpretative and Derivational]. Moscow: Russkii yazyk. Retrieved from https://www.efremova.info/

Yue, X., Leung, C. \& Hiranandani, N. (2016). 'Adult playfulness, humor styles, and subjective happiness'. Psychological Reports $119(3), \quad$ pp. 630-640. https://doi.org/10.1177/0033294116662842. 